\title{
Gra w grze - problem paraludyczności
}

Mateusz Kominiarczuk 


\section{Gra w grze - problem paraludyczności}

Mateusz Kominiarczuk

TEKSTY DRUGIE 2017, NR 3, S. 381-396

DOI: $10.18318 /$ td.2017.3.23

Gry cyfrowe ${ }^{1}$ są powszechnie uznawane za systemy złożone. Mówiąc o złożoności, badacze wskazują przy tym najczęściej na wielość i zróżnicowanie mechanizmów ludycznych, czyli sposobów na wchodzenie przez agensów w interakcje ze stanem gry². Złożoność gier

$1 \quad$ Z pewnymi wyjątkami w humanistyczno-społecznych badaniach nad grami (game studies) wymiennie mówi się o "grach wideo", "komputerowych", ,"elektronicznych" lub "cyfrowych" - por. P. Kubiński Gry wideo. Zarys poetyki, Universitas, Kraków 2016, s. 7; V. Karhulahti Defining the videogame, "Game Studies" December 2015 Vol. 15 issue 2, http://gamestudies.org/1502/articles/karhulahti (17.07.2017). W toku pracy argumentuję na rzecz stosowania bardziej neutralnego i trafniejszego terminu, jakim jest "oprogramowanie rozrywkowe", jednak odwołuję się także do ww. terminów synonimicznych. Jednocześnie wzmianki o "grach" bez dookreślenia odnoszą się zarówno do oprogramowania rozrywkowego (niezależnie od platformy), jak i do gier innego rodzaju (np. towarzyskich - planszowych, karcianych i fabularnych).

2 Por. M. Sicart Defining game mechanics, "Game Studies" December 2008 Vol. 8 issue 2, http://gamestudies.org/0802/articles/sicart (20.07.2016), tłum. własne.

\section{Mateusz}

Kominiarczuk -

doktorant Wydziału

„Artes Liberales" UW.

Jego zainteresowania naukowe obejmują "gry w grach", historię RPG i koncepcje Gerarda Genette'a. Obecnie zajmuje się badaniem złożonych artefaktów ludycznych i gier kompozytowych. Publikował w czasopismach

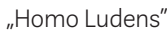
oraz "Literatura i Kultura Popularna". Kontakt: mateusz@ kominiarczuk.com 
można jednak rozumieć również w inny sposób. Jak zauważył Espen Aarseth, wiele gier komputerowych stanowi ludonarracyjne amalgamaty, hybrydy łączące w sobie komponenty ludyczne (tj. growe sensu stricto) i różnorodne treści nieinteraktywne, w szczególności elementy narracyjne. Jego zdaniem metonimiczne określanie "grami” zintegrowanych pakietów multimedialnych prowadzi do nieporozumienia przez zatarcie specyfiki oprogramowania rozrywkowego:

"Gry” nie są po prostu grami, lecz złożonymi programami zdolnymi naśladować dowolne medium, w tym film, tekst/powieść, powieść graficzną, a skoro już o tym mowa - także symulować gry planszowe i sporty. ${ }^{3}$

Spostrzeżenia Aarsetha wpisują się w szerszy nurt rozważań ludoontologicznych, a więc dotyczących przedmiotu współczesnych badań nad grami oraz nad miejscem oprogramowania rozrywkowego na tle innych artefaktów ludycznych, takich jak łamigłówki, zabawki czy gry. Jednym z pionierów podobnego ujęcia w kontekście gier komputerowych jest projektant Chris Crawford ${ }^{4}$. Na gruncie humanistyczno-społecznych badań nad grami ten problem poruszali m.in. Greg Costikyan ${ }^{5}$, Olli Tapio Leino ${ }^{6}$ i Veli-Matti Karhulahti ${ }^{7}$.

Warto zauważyć, że podkreślane przez Aarsetha możliwości symulacyjne gier komputerowych są potencjalnie nieograniczone, co pozwala na zagnieżdżanie w ramach oprogramowania rozrywkowego wszelkich artefaktów ludycznych - nie tylko wspominanych sportów i gier planszowych, lecz także łamigłówek, gier arkadowych (arcade) i innych gier cyfrowych. Powstające na

3 Por. E. Aarseth A narrative theory of games, w: Proceedings of the 2012 Conference on the Foundations of Digital Games, ACM, New York 2012, https://www.researchgate.net/publication/254006015_A_narrative_theory_of_games (27.11.2016), s. 2, tłum. własne.

4 C. Crawford The art of computer game design, 1982, red. wer. cyfr. S. Peabody, Washington State University, Vancouver 1997, http://raws.adc.rmit.edu.au/ e57593/resources/The_Art_of_ Computer_Game_Design/Coverpage.html (16.12.2016).

G. Costikyan I have no words \& I must design: toward a critical vocabulary for games, w: Computer Games and Digital Cultures Conference Proceedings, Tampere University Press, Tampere 2002, http://www.digra.org/wp-content/uploads/digital-library/05164.51146.pdf (16.12.2016).

6 O.T. Leino Death loop as a feature , "Game Studies” December 2012 Vol. 12. issue 2, http://gamestudies.org/1202/articles/death_loop_as_a_feature (16.07.2017).

7 V. Karhulahti Adventures of ludom: a videogame geneontology, University of Turku, Turku 2015; por. tegoż Defining the videogame. 
skutek tego procesu "gry w grze” potocznie określa się „minigrami” (minigames). Za przykład może tu posłużyć cyfrowa gra karciana Gwint będąca częścią opracowanego przez CD Projekt RED pakietu rozrywkowego Wiedźmin 3: Dziki Gon z 2015 r. albo TreeDude włączony do wydanej w 2016 roku niezależnej strzelanki Superhot łódzkiej grupy Superhot Team (omawiane w dalszej części tekstu).

Sięgające swoją historią połowy lat 8o. XX wieku ${ }^{8}$, dodawane do większego pakietu rozrywkowego minigry stanowią przy tym zaledwie jedna stronę zagadnienia, którego dopełnieniem są „metagry” nadbudowywane na grze podstawowej. Zaliczają się do nich w szczególności systemy osiągnięć - zarówno stanowiące integralną część oprogramowania, jak i umocowane w pośredniczącej platformie cyfrowej ${ }^{9}$. Analizowane razem, nie zaś z osobna (jak było w dotychczasowych opracowaniach), różne odmiany „gier w grach" ujawniają swoją właściwą naturę jako paragry (paragames) - przejaw paraludyczności (paraludicity), tj. specjalny przypadek Genette'owskiej paratekstualności ${ }^{\mathbf{1 0}}$.

Kiedy w 2005 roku Microsoft równocześnie z wypuszczeniem na rynek konsoli Xbox 360 przeprowadził reformę platformy sieciowej Xbox Live (XBL), wprowadzenie do niej tzw. osiągnięć (achievements) - specjalnych punktów i odznak przyznawanych graczom za spełnienie określonych warunków w grze - mogło jeszcze wydawać się stosunkowo mało istotnym posunięciem. Ostatecznie nie było to nic nowego: podobnie jak w wypadku minigier, korzenie tego rozwiązania w kontekście rozrywki cyfrowej dają się prześledzić aż do wczesnych lat 8o. XX wieku, a bardziej bezpośrednio - do

8 Por. R. Lambie The strange history of loading screen mini-games, „mental_floss” 26 January 2016, http://mentalfloss.com/uk/games/37627/the-strange-history-of-loading-screen-mini-games (15.12.2016).

9 Zob. J. Hamari, V. Eranti Framework for designing and evaluating game achievements, w: Proceedings of DiGRA 2011: Think Design Play, http://www.digra.org/digital-library/publications/ framework-for-designing-and-evaluating-game-achievements/ (16.11.2014). Por. K. Huotari, J. Hamari Defining gamification - a service marketing perspective, w: Proceedings of the 16th International Academic MindTrek Conference on Media of the Future, ACM, New York 2012, http:// dl.acm.org/citation.cfm?id=2393137 (16.11.2014).

Por. G. Genette Palimpsesty. Literatura drugiego stopnia, przeł. T. Stróżyński, A. Milecki, słowo/ obraz terytoria, Gdańsk 2014, oraz E. Kuźma recenzja Palimpsestes la littérature au second degré G. Genette'a, „Pamiętnik Literacki” 1987 z. 78/2, s. 392-399. Patrz także G. Genette Paratexts: thresholds of interpretation, trans. J.E. Lewin, introd. R. Macksey, Cambridge University Press, Cambridge 1997. 
drugiej połowy lat 9o. XX wieku". Mimo to właśnie aktualizacja Xbox Live okazała się punktem przełomowym i zapoczątkowała jeden z dominujących trendów we współczesnym projektowaniu i dystrybucji oprogramowania rozrywkowego ${ }^{12}$.

Microsoft był pierwszy, jednak widząc efekty, jakie przyniosło producentom Xboxa wprowadzenie tak funkcjonujących osiągnięć, po zbliżone rozwiązania sięgnęły kolejne duże firmy. W 2007 roku osiągnięcia na potrzeby platformy dystrybucji cyfrowej Steam zaadaptowało Valve. W tym samym roku analogiczny system przyjęło w rozszerzeniu World of Warcraft: Wrath of the Lich King studio Blizzard Entertainment. Obecnie z różnie nazywanych osiągnięć, trofeów lub medali korzystają wszyscy więksi producenci i dystrybutorzy cyfrowi, w tym Sony, Apple i Google, a także liczne serwisy udostępniające gry przeglądarkowe, m.in. Kongregate, Armor Games i Newgrounds.

W jeszcze głośniejszy sposób osiągnięcia zostały również zaadaptowane do celów pozagrowych przez strategię marketingową określaną jako „gamifikacja"13. Zgodnie z jej założeniami przyznawanie odznak i punktów ma pozwalać na zwiększenie atrakcyjności poprzez powierzchowne upodobnienie do gier aktywności żmudnych i wymagających wysiłku, jak praca lub ćwiczenia. Kiedy przedmiotem tak rozumianej "gamifikacji” stają się gry, do których trofea dodawane są wtórnie, efekty są znacznie ciekawsze formalnie ${ }^{14}$ - podobnie jak trudności, jakie sprawia to badaczom.

M. Jakobsson The achievement machine: understanding Xbox 360 achievements in gaming practices, "Game Studies" February 2011 Vol. 11 issue 1, http://gamestudies.org/1101/articles/jakobsson (20.07.2016).

Tamże. Por. J. Bycer Understanding the siren song of achievements, "Game Wisdom" 18 September 2013, http://game-wisdom.com/critical/understanding-the-siren-song-of-achievements (23.07.2014).

13 Por. J. Hamari, V. Eranti Framework. Szerzej nt. gamifikacji zob. K. Huotari, J. Hamari Defining gamification; por. z nowszą wersją studium: K. Huotari, J. Hamari A definition for gamification: anchoring gamification in the service marketing literature, "Electronic Markets", Springer, Berlin Heidelberg 2016, http://link.springer.com/article/10.1007/s12525-015-0212-z (29.09.2016). Nt. prekursorów i paralel gamifikacji zob. także: S. Deterding i in. From game design elements to gamefulness: defining "gamification", w: Proceedings of the 15th International Academic MindTrek Conference: Envisioning Future Media Environments, ACM, New York 2011, http://dl.acm.org/citation.cfm?id=2181037.2181040 (15.11.2014), s. 1-2.

Nt. zasadności pozornie tautologicznego zastosowania określenia "gamifikacja" w odniesieniu do projektowania gier zob. M. Kominiarczuk Gamified gameplay: gamification in game design, w: Gamification. Critical approaches, ed. by J. Kopeć, K. Pacewicz, Wydział "Artes Liberales" UW, Warszawa 2015, http://gamification.al.uw.edu.pl/(30.09.2015), s. 83-97. 
Systemy osiągnięć towarzyszące programom rozrywkowym bezpośrednio (jak w World of Warcraft lub Diablo 3 Blizzard Entertainment) lub za pośrednictwem platform cyfrowych (np. Steam względem Superhot, PlayStation Network, Xbox Live i GOG Galaxy w wypadku Wiedźmina 3) najczęściej nazywane są przez badaczy gier „meta-grami” (meta-games) ${ }^{15}$. Główną wadą tego terminu jest jego wieloznaczność. Ta sama nazwa odnosi się również do aktywności, w którą angażują się gracze obierający sobie za cel zdobywanie kolejnych odznak i innych trofeów ${ }^{16}$."Metagra” (metagame) lub po prostu „meta” w żargonie graczy oznacza zarazem najpopularniejsze w danym okresie strategie i zagrania, a "metagranie” (metagaming, „granie metą" lub „pod metę") to sposób na ogranie gry lub przeciwnika (gaming the game, playing a player), ewentualnie wykroczenie poza ramy fikcji w kontekście towarzyskiej gry fabularnej. Wreszcie „metagrami” (metagames) nazywa się w humanistyczno-społecznych badaniach nad grami "gry o grach", a więc oprogramowanie rozrywkowe nacechowane metareferencjalnie ${ }^{17}$ lub, jak proponuje Astrid Ensslin, wykazujące „metaludyczność" (metaludicity) ${ }^{18}$ analogiczną do metatekstualności.

Żeby opanować obserwowany chaos terminologiczny, Marcus Carter, Martin Gibbs i Mitchell Harrop podjęli się zredefiniowania metagier i zaproponowali dwa nowe pojęcia: orto- i paragry ${ }^{19}$. W tej terminologii ortogra (orthogame) wyznacza trzon gry tożsamy z core game w ujęciu Hamariego i Erantiego ${ }^{20}$ : „nieustannie negocjowany wycinek gry, który przez graczy może zostać uznany za fundament lub zupełnie podstawową grę w ramach całej

15 K. Huotari, J. Hamari A definition for gamification, s. 6. Ten sam sentyment można zauważyć u Jakobssona piszącego o systemie osiągnięć będącym częścią platformy Xbox Live, jednak brak tu podobnego rozróżnienia semantycznego - w przekonaniu badacza uwzględnienie systemu osiągnięć przeistacza platformę dystrybucyjno-społeczną w grę sieciową: „Xbox Live Massively Multiplayer Online Game"; por. M. Jakobsson The achievement machine. Jego obserwacja ma zastosowanie także do innych platform tego typu, jak np. Steam wykorzystywany przez Superhot.

Por. J. Hamari, V. Eranti Framework.

Por. M. Carter, M. Gibbs, M. Harrop Metagames, paragames and orthogames: a new vocabulary, w: Proceedings of the 2012 Conference on the Foundations of Digital Games, http://people.eng. unimelb.edu.au/mharrop/metagames.php (22.10.2015).

18 A. Ensslin Playing with rather than by the rules. Metaludicity, allusive fallacy, and illusory agency in ",The Path", w: Analyzing digital fiction, ed. by A. Bell et al., Routledge, New York-London 2014, s. $75-93$.

M. Carter et al. Metagames, paragames and orthogames. 
gry", będący punktem odniesienia dla zróżnicowanych praktyk grania i dodatkowych elementów strukturalnych danego artefaktu ludycznego ${ }^{21}$. Z kolei paragra (paragame) „odnosi się do tego, co odbywa się peryferyjnie, lecz w powiązaniu z ortogrą", w odróżnieniu od metagry opierając się na „pragnieniach i motywacjach graczy zamiast na kontekście gry"22; wśród przykładowych paragier autorzy wymieniają m.in. zdobywanie osiągnięć za pośrednictwem Xbox Live $e^{23}$.Tym samym możliwe jest zerwanie z mylącą koncepcją "gry ponad grą" (gdyż mimo nadbudowania, trofea zachowują raczej status podrzędnych i opcjonalnych) na rzecz nierównorzędnej równoległości.

Propozycja Cartera i innych nie jest wolna od wad. Jej słabość widać zwłaszcza w omówieniu ortogry w odniesieniu do RTS StarCraft Blizzard Entertainment z 1998 roku. Autorzy artykułu słusznie wskazują na trudności ze zdecydowaniem, czy ortogrą jest w tym wypadku kampania dla jednego gracza, czy może wyraźnie różna od niej gra w trybie wieloosobowym ${ }^{24}$; nie przyjmują jednak logicznego wniosku, że oba główne tryby stanowią $\mathrm{w}$ praktyce gry w grze: odrębne i równorzędne części pakietu oprogramowania rozrywkowego, jakim jest StarCraft. Ich terminologia niebezpiecznie zrównuje również praktykę (granie) z jej uwarunkowaniem (grą). Pewniejszym określeniem jest w związku z tym "gra podstawowa" - z zastrzeżeniem, że w ramach jednego tytułu może współwystępować wiele niezależnych gier podstawowych, często określanych (głównymi) trybami gry. Nawet mimo tej poprawki w modelu Cartera i innych brakuje jednak miejsca na szczególny przypadek gier w grach, jakimi są minigry.

Mimo popularności koncepcji Genette'a wśród badaczy gier ani Ensslin, ani Carter i inni nie powołują się na nie w swoich publikacjach. Być może ma to związek z przesyceniem badań nad grami odniesieniami do paratekstualności, z którą wiąże się zupełnie dowolne materiały towarzyszące oprogramowaniu rozrywkowemu: od opakowań i instrukcji, aż po filmowe zapowiedzi, wersje demonstracyjne (dema) i inne materiały marketingowe ${ }^{25}$.

\footnotetext{
21 M. Carter et al. Metagames, paragames and orthogames, s. 4, tłum. własne. 
Niezależnie od nieobecności dzieł Genette’a w bibliografiach badaczy zarówno „paragry”, jak i „metaludyczność” pozostają całkowicie spójne z koncepcjami francuskiego teoretyka, a przy tym bliskie im stylistycznie. Naturalna wydaje się w związku z tym propozycja ich połączenia. Paraludyczność (przez analogię do paratekstualności) byłaby zatem cechą gier i ich elementów, które pozostają w takiej relacji z grą podstawową, jak parateksty z tekstem dzieła ${ }^{\mathbf{2 6}}$. Idąc dalej: za paragry należy uznać nie tylko nadbudowane gry peryferyjne (perigames) w rodzaju systemów osiąnięć - ściśle powiązane z grą i zależne od niej, a zarazem osobne ${ }^{27}$ - lecz także ich daleko słabiej zbadane ludoontologiczne dopełnienie, jakim są gry towarzyszące, inaczej minigry.

„Minigra” (minigame) to w roku 2016 termin zupełnie powszechny w żargonie odbiorców, twórców i krytyków oprogramowania rozrywkowego, stosowany nawet do najstarszych gier cyfrowych bez poczucia anachroniczności ${ }^{28}$. Zależnie od kontekstu określenie to odnosi się najczęściej albo do niewielkich, mało złożonych gier symulowanych i zagnieżdżanych w ramach większych produkcji (zwłaszcza gier komputerowych z otwartym światem, np. Grand Theft Auto IV, Red Dead Redemption lub Wiedźmin 3: Dziki Gon), albo też dystrybuowanych niezależnie w pakietach obejmujących od kilku do kilkuset pozycji - całkowicie odrębnych lub powiązanych strukturą nadrzędną (jak Mario Party lub WarioWare). Minigry bywają także zrównywane z wydarzeniami (events) oraz zadaniami pobocznymi (sidequests) $^{29}$.

Pierwszą i przez długi czas jedyną publikacją akademicką na temat minigier w perspektywie groznawczej był artykuł Amina Tavassoliana, Kevina G. Stanleya, Carla Gutwina i Aryana Zohooriana ${ }^{30}$. Niezależnie od tego już wcześniej powstawały pojedyncze studia dotyczące gier w grach, nie były

26 Por. G. Genette Paratexts, s. 2.

27 Por. tamże, s. 5.

Por. D. Cornelius Megumi rescues, „Sega Does” 20 June 2015, https://segadoes.com/2015/06/20/ megumi-rescue/ (15.12.2016). Por. Final Fantasy VII PlayStation Manual (North America), 1997, "Final Fantasy Wiki”, http://finalfantasy.wikia.com/wiki/Final_Fantasy_VII/Manual/North_America\#pg18, oraz hasło: Sidequest, "Zelda Wiki", http://zeldawiki.org/Sidequest (15.12.2016).

A. Tavassolian, K.G. Stanley, C. Gutwin, A. Zohoorian Time balancing with adaptive time-variant minigames, w: Entertainment Computing - ICEC 2011, ed. by J. Anacleto et al., Springer, Berlin Heidelberg 2011, s. 173-185. 
one jednak związane z problematyką minigier jako takich. Za przykład może tu posłużyć opracowanie Ragnhild Tronstad, w którym jako gry rozpatrywane są zadania (quest) w grach MUD ${ }^{31}$. Dopiero w ostatnich dwóch latach właściwe minigry zyskały sobie większą uwagę badaczy, przy czym najdalej posunął się dotychczas Hans-Joachim Backe, autor niemieckojęzycznej komparatystycznej rozprawy o grach w grach oraz uprzedniego względem niej wystąpienia konferencyjnego na ten sam temat ${ }^{32}$. W Polsce pokrewną tematyką zainteresowało się dotychczas trzech badaczy: Paweł Grabarczyk (odnoszący się przede wszystkim do trybów gier, game modes, nie zaś do minigier), Krzysztof M. Maj i Mateusz Kominiarczuk ${ }^{33}$. Już z uwagi na tak ograniczone zaplecze akademickie wszelkie rozważania nad zagadnieniem gier w grach powinny być poparte badaniami w zakresie funkcjonowania samego terminu.

W Słowniku gracza serwisu Gry-Online.pl hasło „minigra” zostało opatrzone zrzutem ekranu z opracowanej przez Bethesda Game Studios i wydanej w 2008 roku przez Bethesda Softworks wieloplatformowej gry Action RPG Fallout 3, na którym widoczna jest zręcznościowa próba otwarcia zamka. Szerzej hasło objaśniane jest jako:

Rodzaj prostej gry, najczęściej o charakterze zręcznościowym lub logicznym. Zazwyczaj minigra jest elementem większej produkcji, w której pełni rolę jednego z wyzwań stawianych przed graczem lub przerywnika urozmaicającego właściwą rozgrywkę. Czasami minigry bywają

R. Tronstad Semiotic and Non-Semiotic MUD Performance, w: COSIGN 2001 Proceedings, Stichting Centrum voor Wiskunde en Informatica, Amsterdam 2001, http://www.cosignconference. org/conference/2001/papers (29.11.2016).

H.J. Backe Das Spiel im Spiel - im (Computer-)Spiel, w: Vergleichen an der Grenze. Beiträge zu Manfred Schmelings komparatistischen Forschungen, Hrsg. von H.J. Backe, C. Schmitt, C. Solte-Gresser, Königshausen \& Neumann, Würzburg 2016, s. 37-74. Por. H.J. Backe Minigames as metareference, w: Proceedings of the 2015 DiGRA International Conference: diversity of play: games - cultures - identities. Odwołania do prac Backego znajdują poparcie w tekście, a równocześnie odzwierciedlają prywatną wymianę uwag nt. funkcjonowania gier w grach.

We wszystkich wspominanych przypadkach brakuje dotychczas publikacji recenzowanych z wyjątkiem ew. abstraktów konferencyjnych, por. P. Grabarczyk Games within games: how to properly individuate game modes, DiGRA 2015; K.M. Maj The dialectics of immersion: minigames, gameworld, and world-building, Games and Literary Theory 2016, https://gameslit16. wordpress.com/the-dialectics-of-immersion-minigames-gameworld-and-world-building/ (17.07.2017); M. Kominiarczuk Games-in-games: mini-and meta-games, CEEGS 2015; tegoż Frame analysis as an interpretative tool for games within games, CEEGS 2016. 
wydawane w kompilacjach (np. O.M.G.26-Our Mini Games) przeznaczonych głównie do odbiorców z rynku tzw. casuali (okazjonalnych graczy). ${ }^{34}$

Ze skróconej wersji definicji Gry-Online.pl korzysta m.in. polskojęzyczna Wikipedia, podkreślająca rozmiar („mała”) i relację z innym tytułem („dodatkowa gra”, „przerywnik urozmaicający właściwą rozgrywkę”); wreszcie - wskazuje na typowe rozwiązania („charakter zręcznościowy lub logiczny”) i odsyła do kategorii „casual games” i ich odbiorców ${ }^{35}$. Wikipedyjne hasło w języku angielskim jest zbliżone, ale znacznie bardziej rozbudowane. Poruszane są w nim te same kategorie (pojawia się również odsyłacz do „casual games”), lecz dodatkowo zostały odnotowane alternatywne zapisy pojęcia (minigame, mini-game, mini game) oraz określenia synonimiczne (1. subgame, dosł. „podgra” albo "gra podrzędna”; 2. microgame „mikrogra”). Znalazło się również miejsce na problemy dystrybucji i funkcji minigier:

Minigra [...] to krótka gra wideo, często zawarta w innej grze, a czasem w oprogramowaniu użytkowym lub na wyświetlaczach wszelkiego rodzaju urządzeń. Minigra jest zawsze mniejsza lub prostsza niż gra, która ją zawiera. Minigry są często nieodpłatnie udostępniane oddzielnie, by promować główną grę. [...] Minigry funkcjonują również jako dodatkowe etapy lub ukryte poziomy. ${ }^{36}$

W dalszej części hasła podawane są przykłady minigier funkcjonujących jako element większej gry, urozmaicenie w trakcie oczekiwania na wczytanie programu lub „ukryte gry” towarzyszące oprogramowaniu użytkowemu, a także w większych pakietach, zwłaszcza jako tzw. gry imprezowe (party ga$m e s)^{37}$. Już na tym etapie widoczne jest pęknięcie: z jednej strony minigry wiąże się z większymi produkcjami dla zaangażowanych graczy ([hardcore]

Hasło: Minigame, „Wikipedia”, https://en.wikipedia.org/wiki/Minigame (15.10.2016), tłum. własne.

37 
gamers), z drugiej - ze zbiorami małych gier dla graczy niezaangażowanych (casual $[$ gamers $])^{\mathbf{3 8}}$.

Na gruncie akademickim o minigrach albo pisze się w podobnie środowiskowy sposób, albo też interpretuje się je w kontekście metareferencji i teorii światów możliwych ${ }^{39}$ oraz immersji i emersji ${ }^{40}$. Amin Tavassolian i pozostali autorzy opracowania na temat perspektyw praktycznego zastosowania minigier w grach wieloosobowych wpisują się jeszcze w pierwszą z wymienionych interpretacji, co wyraźnie widać w sformułowanej przez nich definicji - bliskiej wikipedyjnym:

Minigry to proste zajęcia zawarte w większej grze, częste w tytułach komercyjnych (np. Mario Party, Sid Meier's Pirates! lub Assassin's Creed 2) ${ }^{41}$. [...] Zazwyczaj minigry stanowią krótkie, samodzielne rozgrywki $\mathbf{i n}^{\mathbf{4 2}}$ zawarte w ramach większej gry, lecz przy tym posiadające własną wewnętrzną logikę, stan gry i mechaniki. ${ }^{43}$

Główną innowacją autorów w porównaniu z przytaczanymi wcześniej definicjami obiegowymi jest podkreślenie samodzielności rozgrywki minigrowej oraz jej wyznaczników, co - jak zauważa Backe - w znaczniej mierze uwalnia tak rozumiane gry w grach od problemów napotykanych przy analizie osiągnięć i podobnych systemów. Wyjątek stanowią tu jedynie gry w rodzaju wspomnianej serii Mario Party, którym bliżej do zbioru luźno

38 Wypada odnotować, że w żargonie graczy opozycja "hardcore gamer" - "casual gamer" często bywa sprowadzana do przeciwstawienia "gracza-gamera" (zaangażowanego, autentycznego) "Casualowi" (niezaangażowanemu, okazjonalnemu), którego pozbawia się tym samym prawa do miana "gracza"; por. M. Garda Interaktywne fantasy, s. 110-116.

Por. H.J. Backe Minigames as metareference; S. Deterding, The game frame: systemizing a Goffmanian approach to video game theory, w: Breaking new ground: innovation in games, play, practice and theory. Proceedings of DiGRA 2009, http://www.digra.org/digital-library/publications/ the-game-frame-systemizing-a-goffmanian-approach-to-video-game-theory-extendedabstract/ (11.06.2016), s. 2.

Por. K. Maj The dialectics of immersion.

A. Tavassolian et al. Time balancing, s. 174, tłum. własne.

W oryginale: „short, self-contained play experiences" (dosł. "krótkie, samozawarte doświadczenia grania"). W polskich badaniach nad grami „rozgrywka” jest właściwie traktowana jako odpowiednik ang. gameplay, który z play experiences pozostaje w relacji metonimicznej jako ich podstawowe uwarunkowanie.

43 A. Tavassolian et al. Time balancing, s. 175, tłum. własne. 
połączonych małych gier ${ }^{44}$. Notabene autorzy przytoczonej definicji w ogóle nie odnoszą się wprost do kategorii casual game, przez przywołanie imprezowego Mario Party odsyłają jednak do tego samego kręgu znaczeń. Wydaje się ponadto, że Tavassolian i inni nie brali pod uwagę przypadków uniezależnienia się gry pierwotnie pomyślanej jako składowa pakietu oprogramowania rozrywkowego, mimo że w artykule opierają się na przypadku odwrotnym: wykorzystania adaptacji uprzednio istniejących gier w nowym kontekście ${ }^{45}$.

Ciekawsze jest stanowisko zajmowane przez Backego, który traktuje gry w grach jako zabieg metareferencjalny i sytuuje je w kontekście podobnych rozwiązań w dramacie i prozie:

minigry wytwarzają rekursywne struktury podobne do spotykanych w prozie (powieść szkatułkowa) i dramacie (sztuka w sztuce), komentując zarówno gry je zawierające, jak i gry w ogóle ${ }^{46}$.

Stanowisko to łatwo uargumentować, czerpiąc przykłady z takich gier jak GTA IV czy Superhot i cała seria Wiedźmin - autotematycznych i często korzystających z rozmaitych środków emersyjnych w celu zbudowania dystansu ironicznego ${ }^{47}$. W każdej z trzech dotychczasowych gier z serii programów rozrywkowych CD Projekt RED o wiedźminie Geralcie twórcy oferują graczom wybór kilku gier towarzyszących. Pojedynki pięściarskie, wyścigi konne (tylko Wiedźmin 3: Dziki Gon) i kościany poker (tylko Wiedźmin i Wiedźmin 2: Zabójcy królów) są grami zagnieżdżonymi - dostępnymi z poziomu świata gry (nie zaś np. menu), a przy tym przynajmniej częściowo wydzielonymi pod względem sterowania i stanu gry (z miejscem na wygraną lub porażkę w grze towarzyszącej bez większego wpływu na całokształt rozgrywki, a często też

44 Por. H.J. Backe Minigames as metareference, s. 2.

45 A. Tavassolian et al. Time balancing.

H.J. Backe Minigames as metareference, s. 1, tłum. własne. Wspominając o literackiej „opowieści w opowieści", Backe pisze dosłownie o mise en abyme (z francuskiego mise en abîme). Jakkolwiek pojęcie to nie jest obce polskiemu literaturoznawstwu, w tym kontekście jego najbliższym odpowiednikiem wydaje się właśnie "powieść szkatułkowa”. Należy przy tym pamiętać, że samo mise en abîme jest znacznie szerszym znaczeniowo terminem, który może się odnosić do wszelkich przypadków wykorzystania artystycznego samopodobieństwa i rekursji w dziele.

Zob. P. Kubiński Dystans ironiczny w grach Wiedźmin i Wiedźmin 2: Zabójcy królów, w: Wiedźmin - bohater masowej wyobraźni, red. R. Dudziński i in., Trickster, Wrocław 2015, http://tricksterzy. pl/download/wiedzmin/ (15.11.2016), s. 113-126. Por. finalna wersja rozdziału w: P. Kubiński Gry wideo, s. 95-113. 
z możliwością wielokrotnego podejmowania wyzwania). Wszystkie wymienione pozostają zarazem na tym samym poziomie ontycznym i raczej podtrzymują, niż podważają iluzję spójnego świata. Na tym tle odznacza się karciany Gwint wprowadzony w Dzikim Gonie.

W pierwszym rzędzie zwraca uwagę niedopasowanie Gwinta do realiów świata Wiedźmina 3, w drugim - jego autonomiczność i zaskakująco wysoka pozycja w całościowej strukturze programu. Dobrze ilustruje to instrukcja dostępna z poziomu menu Wiedźmina 3, w której część poświęcona zagnieżdżonej grze karcianej jest prawie równie rozbudowana jak cała reszta. Analogicznie działa decyzja o przypisaniu Gwintowi osiągnięć na tych samych prawach, co grze podstawowej, przez co dochodzi do splecenia dwóch paragier: peryferyjnych trofeów i zagnieżdżonej gry karcianej. Ostatecznie o rzadkiej autonomii tej szczególnej gry towarzyszącej decydują dalsze działania CD Projekt RED - najpierw dołączanie papierowych talii kart (wraz z zasadami) do pudełkowych wydań rozszerzeń do Wiedźmina 3 - Serc z kamienia (2015) oraz Krwi i wina (2016), a następnie wydanie Gwinta jako samodzielnej, rozbudowanej i dopracowanej cyfrowej gry karcianej na komputery i konsole (2017). Podobną drogę pokonała wcześniej m.in. karcianka Arcomage

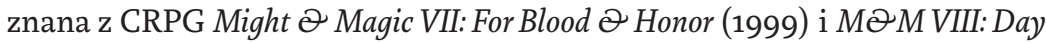
of the Destroyer (200o). Podobieństwa między Gwintem a Arcomage sięgają zresztą dalej.

Inaczej niż w poprzednich grach z serii o wiedźminie Geralcie, w których graczom oferowano na podobnych zasadach możliwość gry w kości, Gwint wyraźnie wykracza poza realia fantastycznego świata wzorowanego na literackiej kreacji Andrzeja Sapkowskiego. Przede wszystkim oprawa gry karcianej opiera się na fotorealistycznych przedstawieniach bohaterów komputerowej serii. Sama formuła rozgrywki raczej niż do tradycyjnych gier karcianych nawiązuje przy tym do kolekcjonerskich karcianek w duchu Magic: the Gathering Richarda Garfielda (od 1993 roku) i ich cyfrowych naśladowców w rodzaju wspominanego już Arcomage lub Hearthstone Blizzard Entertainment (od 2014 roku), z którymi łączy Gwinta również minimalistyczna ikonografia i sposób rozmieszczania kart na stole. W tej konstrukcji można upatrywać przypadku jawnej metalepsy ${ }^{48}$, a zarazem radykalnego zabiegu emersyjnego ${ }^{49}$. Możliwa jest jednak inna interpretacja.

48 Por. H.J. Backe Minigames as metareference, s. 1.

49 Por. K. Maj The dialectics of immersion i P. Kubiński Gry wideo. 
Zbliżony przypadek rozpoznał Backe piszący o „ostentacyjnych w swej growości" grach zagnieżdżonych reprezentujących nietrywialne czynności ${ }^{50}$. Choć tego rodzaju gry towarzyszące mogą funkcjonować w ścisłej relacji ze światem i stanem gry, nie mają one zarazem charakteru diegetycznego. Tak jest i z Gwintem: od kościanego pokera, którego miejsce zajął w systemie Wiedźmina, bliżej byłoby mu do omawianej przez Backego symulacji hakowania w Bioshock studia 2K Games z 2007 roku $^{51}$. Nowoczesna ikonografia, fotorealistyczna oprawa i współczesna mechanika Gwinta nie byłyby przy tym ani narzędziem światotwórczym, ani celowym zabiegiem emersyjnym, ani nawet metalepsą. To raczej metonimia - swobodny przekład funkcjonalny sytuacji "gry w karty" w formie atrakcyjnej dla gracza implikowanego ${ }^{52}$. Analogicznie można interpretować przypadek Arcomage.

Mimo poczynionych wcześniej uwag, w wydaniu pierwotnym Gwint jest tylko częściowo autonomiczny: $\mathrm{w}$ dostosowanym dla pojedynczego gracza świecie Wiedźmina nie ma możliwości gry z ludzkimi przeciwnikami. Co więcej w celu rozgrywania kolejnych partii Gwinta grający w Dziki Gon muszą podróżować po świecie gry, gromadząc karty i wchodząc w interakcje z napotykanymi postaciami. Z jednej strony Gwint pozostaje przez to uwikłany w kontekst gry nadrzędnej, z drugiej - Wiedźmin 3 przyjmuje rolę gry ramowej względem zagnieżdżonej w nim gry karcianej. Można tu mówić o szczególnym wypadku świata-interfejsu ${ }^{53}$, co paradoksalnie zbliża w pełni trójwymiarowego Wiedźmina do szczycącej się swoim minimalizmem, w znacznej mierze tekstowej oprawy Superhot.

Inspirowany m.in. filmowym Matrixem Wachowskich Superhot jest o tyle złożonym przypadkiem, że opiera się na koncepcji nie tylko gry w grze, ale programu w programie. Próba uruchomienia gry przenosi gracza do fikcyjnego systemu operacyjnego Omni piOS pełniącego funkcję diegetycznego $\mathrm{menu}^{54}$ Superhot; dopiero za jego pośrednictwem uruchamiany jest FPS pod tym tytułem, a (po pierwszym przejściu gry) także różne tryby gry. Już sam tekstowy szuk, "Kultura i Historia” nr 13/2008, http://www.kulturaihistoria.umcs.lublin.pl/archives/884
(17.07.2017).

H.J. Backe Minigames as metareference, s. 2

Tamże.

Por. E. Aarseth Walczyłem przeciw prawu: wywrotowa gra i gracz implikowany, przeł. P. Wojcie-

Por. K. Jørgensen Gameworld interfaces, The MIT Press, Cambridge-London 2013.

Por. pojęcie metainterfejsu - P. Kubiński Gry wideo, s. 182-187 i s. 212-214. 
interfejs piOSa (białe i szare litery na czarnym tle naśladującym krzywiznę i kształt ekranu monitora kineskopowego ${ }^{55}$ ) można odczytywać jako odniesienie do lat 9o. XX wieku, kiedy powstał Matrix; więcej odwołań można się dopatrzeć w projekcie poziomów i treści wiadomości rozsianych po etapach gry. Przeglądając piOSowe katalogi, użytkownik może odnaleźć ASCII-Art oraz dema ${ }^{56}$, a także drugą grę: TreeDude - wykonany w estetyce ASCII-artowej klon wieloplatformowej polskiej casualowej gry arkadowej Timberman studia Digital Melody (nawiązujący do pierwowzoru już kalką tytułu).

TreeDude jest "grą ukrytą" tylko o tyle, że nie wyświetla się na pierwszym ekranie menu - dostęp do niego wymaga otwarcia w piOSie katalogu „Games". Nie funkcjonuje wobec Superhot ani na zasadach gry pomocniczej (auxiliary game) wczytywanej w trakcie ładowania głównego programu, w odróżnieniu od typowych gier zagnieżdżonych nie jest też dostępny ściśle z poziomu gry podstawowej. Stanowi natomiast element kreacji alternatywnego świata gry. Można w nim widzieć zarówno nawiązanie do wielokrotnie przywoływanej w Superhot subkultury hakerskiej, jak także ukłon twórców wobec innej niezależnej polskiej grupy tworzącej gry cyfrowe. Jak jednak wskazuje Backe, jako cyfrowa gra w grze cyfrowej TreeDude ma wysoki potencjał metareferencyjny ${ }^{57}$, ujawniający się zresztą na poziomie podstawowej mechaniki gry: powiązania upływu czasu z działaniami gracza. O ile we właściwym Superhot czas jest dla gracza narzędziem - płynie powoli i przyśpiesza tylko wtedy, gdy awatar się porusza, skłaniając do nietypowego dla strzelanek strategicznego podejścia - o tyle w TreeDude/Timberman odwrotnie: czas jest wyzwaniem. Od pierwszego wykonanego ruchu czas w stale widocznym liczniku wyczerpuje się (coraz szybciej w toku rozgrywki), gdy gracz nie podejmuje żadnych działań, i jest uzupełniany przy każdym kolejnym posunięciu, wymuszając szybką grę. To kontrapunktowe sprzężenie mechanik gry podstawowej i towarzyszącej pozwala sproblematyzować relację czasu i kontroli (inaczej sprawczości), będących głównymi tematami całego Superhot.

$\mathrm{Na}$ uwagę zasługują również podobieństwa peryferyjnych warstw paraludycznych Wiedźmina 3 i Superhot. W Dzikim Gonie osiągnięcia występują wprawdzie obok nieobecnych w Superhot zadań (zbliżoną do nich funkcję

55 Z podobnego chwytu korzystają niekiedy także inne programy, m.in. opublikowana w 2015 roku niezależna kryminalna gra filmowa autorstwa Sama Barlowa pt. Her Story. Notabene również ten utwór zawiera w sobie grę zagnieżdżoną: Mirror Tiles.

H.J. Backe Minigames as metareference. 
pełnią jednak cele misji), z którymi częściowo się pokrywają - podobnie jak te ostatnie odmierzają postępy w grze i nadają strukturę rozgrywce osadzonej w otwartym świecie, skłaniając graczy do poszukiwań i specjalnych zagrań. Wspólna obu grom jest natomiast niepowtarzalność osiagnięć, odróżniająca je od zadań bardziej jeszcze niż wyodrębnienie i brak bezpośredniego przełożenia tych pierwszych na stan gry podstawowej. Być może ktoś zdecyduje się na kilkukrotne przejście Dzikiego Gonu i wykona przynajmniej częściowo te same zadania więcej niż raz; związane z nimi trofea zostaną jednak przyznane tylko za pierwszym razem. Podobnie w Superhot, gdzie gracze wielokrotnie podejmują próby przezwyciężenia stawianych przez grę wyzwań; nawet po wyczyszczeniu gry i ponownym rozpoczęciu części fabularnej nie uda się jednak otrzymać danego odznaczenia po raz drugi. $\mathrm{Na}$ tle właściwej grom powtarzalności peryferyjny system osiągnięć zaskakuje więc jednorazowością.

Jeśli w dalszym ciągu konieczny jest jakiś argument, by przynajmniej na gruncie akademickim zaprzestać mówienia o „metagrach” w odniesieniu do warunkujących poczucie ciągłości i formujących strukturę gry kampanii fabularnych czy systemów osiągnięć, tudzież o „minigrach” w kontekście gier w grach, to dostarcza go rozwój branży gier i wypowiedzi jej przedstawicieli. Coś, co mogło być igraszką, sekretem, przerywnikiem lub prostym narzędziem marketingowym w latach 8o. minionego stulecia, już teraz urasta do rangi dominanty kompozycyjnej, a mimo to pozostaje niemal niezauważone. Tymczasem twórcy masowych gier sieciowych (MMOG - massive multiplayer online games, np. World of Warcraft) wprost mówią o grach w kategoriach złożonych, przenikających się (wszech)światów mających trafić nie do jednej konkretnej grupy graczy, ale do wielu mniejszości o najróżniejszych oczekiwaniach i o usieciowionej, przenikanej grami przyszłości ${ }^{58}$. Andrew Wilson, prezes zarządu Electronic Arts - jednej z największych firm w branży oprogramowania rozrywkowego - snuje wręcz wizje nieodległej przyszłości, w której gry przenikają całe ludzkie życie ${ }^{59}$. Fundamentem tych

58 J. Benson Why Blizzard can't please everyone, "Kotaku” 10 May 2016, http://www.kotaku.co.uk/2016/05/10/why-blizzard-cant-please-everyone (21.06.2016). Por. B. Crecente The Division isn't just Ubisoft's next game, it's the company's future, "Polygon" 8 March 2016, http://www. polygon.com/features/2016/3/8/11179934/ubisoft-division-interview-future-watch-dogs-2 (16.03.2016).

C. Plante EA CEO Andrew Wilson interview: your life will be a video game, "The Verge" 16 November 2016, http://www.theverge.com/a/verge-2021/ea-ceo-andrew-wilson-interview-virtualvideo-games (16.11.2016). 
technoproroctw są właśnie struktury paraludyczne; tym bardziej konieczne jest uczynienie ich przedmiotem pogłębionych studiów.

\section{Abstract}

\section{Mateusz Kominiarczuk}

UNIVERSITY OF WROCŁAW

The Game in the Game: The Problem of the Paraludic

Kominiarczuk proposes a new descriptive language that would facilitate a more effective analysis of complex games though a preliminary definition of terms such as: basic game, peripheral game, nested game and accompanying game. Besides other titles, two Polish productions serve as the main source of examples: The Witcher 3: Wild Hunt, a big-budget role-playing video game played in an open world, as well as the independent shooter video game Superhot. From a theoretical perspective, the article is based on current ludoontological research on the components of complex games - so-called metagames and minigames - juxtaposed with the works of Gérard Genette. The analogy to Genette's paratextuality allows Kominiarczuk to postulate the recognition of the game within the game as a manifestation of the paraludic.

\section{Keywords}

complex games, ludo-ontology, metagames, minigames, paraludic 